\title{
VĒL KĀDA LAPPUSE PROFESORA PAULA STRADIN̦A VAJĀŠANAS HRONIKĀ (pagātnes liecības publikācija)
}

Mazizmantots Latvijas medicīnas vēstures avots vēl aizvien ir bij. LKP arhīva dokumenti, kas agrāk bija pieejami ierobežotam pētnieku lokam. Tie satur pietiekami vērtīgus datus laikmeta un arī gluži konkrētu cilvēku raksturojumam. Slepenība, kas valdīja kompartijas sapulcēs un darbībā, atšķirot to no pārējās sabiedrības, tika saglabāta arī dokumentācijā, kura bieži vien pietiekami precĩzi atspoguloja patieso stāvokli, kas sabiedrībai tika slēpts un liegts it kā svešam (tautas!) skatienam. Atklātỉba, kas demagogiski tika pieprasīta no kompartijas biedriem, sapuľ̌u gaitā nereti izpaudās aizmuguriskas informācijas sniegšanā par bezpartijiskiem darbabiedriem un kolēgiem. Turklāt slēgtajās sapulcēs jau nekādas īpaši slepenas lietas parasti apspriestas netika, jo loti bieži tie bija ikdienas darba jautājumi, kas tika apspriesti krietni atklātāk, nekā kopā ar pārējiem, bezpartijiskajiem. Tad arī tika sagudroti vadoši, it kā partijas vārdā doti norādījumi, ieceres un plāni. Taču slepenība, kuras aizmugurē atradās varas represīvais aparāts, cilvēkos iedvesa bailu sajūtu. Nereti kompartijas organizācija tika izmantota atsevišḳu tās biedru personisko rēḳinu kārtošanai ar bezpartijiskajiem, arī karjeras nolūkā.

Profesora Paula Stradiṇa biogrāfiskās deta|as LKP arhīvā līdz šim ir tikušas meklētas maz, jo viņš nebija kompartijas biedrs, taču dokumenti liecina, ka dažāda līmeña sapulcēs, sēdēs un tamlīdzīgos saietos viṇš ir ticis minēts pietiekami bieži. Š̉ai gadījumā galvenokārt pārlūkoti LVU kompartijas organizācijas saglabātie dokumenti, kas aptver laikposmu no 1945. līdz 1950. gadam.

Pēckara gados pret profesoru bija vērstas divas lielas politiska rakstura kampaṇas ar cilvēciskiem pazemojumiem un it kā vina ideologisku pāraudzināšanu. Pirmā virsotne tika sasniegta 1947. gada 2. oktobrī, kad P. Stradinňs tika kritizēts Latvijas PSR Zinātñu akadēmijas pilnsapulcē par nepārdomātiem izteicieniem Baltijas republiku Veselības aizsardzības ministriju Medicīnas zinātnisko padomju 3. apvienotajā sesijā Viḷnā, bet apogejs sekoja 1949. gada 21. oktobrī, kad LPSR Veselības aizsardzības ministrijas Medicīnas zinātniskās padomes 
prezidija un LVU Medicīnas fakultātes zinātniskās padomes kopējā sēdē P. Stradiṇ̌s sañēma asus pārmetumus "par kādu kaitīgu lekciju". Šie materiāli jau ir publicēti ar pietiekami plašiem komentāriem [1]. Taču bija arī daudzi sīkāki un visai bieži uzbrukumi profesoram, par kuriem zināms mazāk.

P. Stradiṇa kritizēŠana pakāpeniski sāka iezīmēties pēc viṇa aiziešanas no Medicīnas fakultātes dekāna posteña 1946. gada 1. septembrī (biogrāfiskajā literatūrā ir stabili ieviesies neprecīzs datējums ar 1947. gadu, kas atrodams arī profesora personīgi aizpildītās vēlāku gadu anketās). Laika ziṇã tas atbilda politiskās situācijas izmaiṇai PSRS pēc VK(b)P CK lēmuma par žurnāliem Zvezda un Leņingrad 1946. gada augustā un atbilstīgām LK(b)P CK sekretāra Arvīda Pelšes iniciatīvām Latvijā nedaudz vēlāk. 1946. gada 4. oktobrī notika LK(b)P CK biroja sēde, kurā tika apspriesta LVU darbība, konstatējot daudzus trūkumus ideologiskā darbā, kam vēlāk sekoja augstskolas politiskā tīrīšana un sakārtošana, kas iespaidoja arī P. Stradinna likteni.

Ja tūlīt pēc kara P. Stradiña vārds augstskolas kompartijas organizācijas dokumentos pavīd epizodiski un ar atzin̄̄bu, piemēram, uzzinājuši par profesora saistošo muzeju, 1945. gada 8. decembrī Medicīnas fakultātes komunisti nolemj to apmeklēt [2], tad tā vairs nav kopš 1946. gada rudens, kad aina k|ūst savādāka. Gatavojot iepriekšminēto LK(b)P CK biroja sēdi, LVU fakultāšu darba pārbaudi veica īpašas komisijas. Medicīnas fakultāti pārbaudīja "brigāde" (kā minēts dokumentā) septiṇu cilvēku sastāvā, kas sagatavoja un 1946. gada 1. oktobrī iesniedza pārskatu uz 31 lapas. Komisiju vadīja veselības aizsardzības tautas komisārs Ernests Ameriks, bet aktīvākais pārbaudītājs bija docents Leonīds Go|bers. Părskatã negatīvi raksturoti gandrīz vai visi vietējas izcelsmes Medicīnas fakultātes mācībspēki, kas jau lauj saskatīt attieksmi pret P. Stradinu kā fakultātes atjaunotāju.

Profesora autoritāte tomēr bija pietiekami liela un ar to rēḳinājās, tāpēc komisijas ziṇojumā viṇš personīgi tiek aizskarts mazāk nekā citi, ja neṇem vērā divas "indīgas" piezīmes - kopā ar profesoriem Ernestu Putniṇu, Kristapu Rudzìti un docenti Martu Vīganti viņš minēts starp tiem, kas uzskatot, ka "padomju valsts limitējot zinātnes attīstību", bet P. Stradina kabinetā katedrā esot skatāmi to profesoru portreti, "kas aizbēguši kopā ar vāciešiem" [3] (domājams, Jēkabs Alksnis un Jānis Šulcs).

Vēlāk, apspriežot šo ziņojumu CK biroja sēdē 1946. gada 4. oktobrī, biroja loceklis Pēteris Plēsums minēto papildināja, ka arī P. Stradiña gimene esot neuzticama - sieva N̦ina Stradiña esot baltemigrante, bet dēls pusaudzis Jānis kolekcionējot ideolog̀iski kaitīga satura himnas [4].

Ja 1946. gada 20. septembrī jaunieceltais dekāns profesors Aleksandrs Šmits fakultātes komunistiem, kritizējot citas katedras, ziṇo, ka P. Stradiña katedrā viss "ir labi" [5], tad drīz vien sāk parādīties dažādi trūkumi gan mācību, gan zinātniskā, bet it īpaši - politiskās audzināsanas darbā. Ar it kā maznozīmīgiem, nesvarīgiem aizrādījumiem tiek gatavota augsne turpmākām kritikas kampanām. 
Pakāpeniski pieaugot, 1949. gadā Paulam Stradinam adresētā kritika jau k|ūst regulāra un pat sistemātiska, kas vedina domāt par tās īpašu organizēšanu.

Publicētais dokuments liecina jau par augstāka līmeña sasnieǧ̌anu P. Stradiṇa vajāšanā 1949. gada vasarā. Tas ir uzlūkojams par pakāpienu, it kā prelūdiju, uvertīu tā paša gada oktobra kampanai, kas kluva par vissāpīgāko pagrieziena punktu profesora mūžã.

Divas klīnikas jaunās asistentes, Galija N̦ikitina-Stepanova un Aleksandra Maslovska, LVU kompartijas birojam bija iesnieguŠas sūdzību par P. Stradinu. Tās izmeklēšanai tika izveidota "brigāde" uz Rīgu nule atbraukušā profesora Nikolaja Danilova vadībā, un 1949. g. 21. jūnijā notika biroja sêde, kas pieñēma atbilstīgu lēmumu. Arhīvā neizdevās atrast ne iesniegumu, ne arī "brigādes apsekoß̌anas aktu", tālab tiek citēts tikai sēdes protokols un biroja lēmums, kuri ir pietiekami pārliecinoši un dai|runīgi pat bez īpašiem komentāriem.

Tomēr jāatzīmē, ka abas sūdzētājas bija pārkāpušas kompartijā pieṇemto hierarhisko kārtỉbu, iesniegumu adresējot augstākstāvošai instancei, bet ne fakultātes kompartijas pirmorganizācijai, domājams, necerot gūt tās atbalstu. Arī sūdzības motivācija ne tik daudz ir saistīta ar P. Stradina politisko neuzticamību, cik ar nevēlēšanos izvirzīt jaunās kolēgeses, tătad dominē savtīgas karjeras motīvi demagogiskā aizsegā. Neraugoties uz ska|jajām frāzēm, biroja lēmums tomēr ir pietiekami saudzīgs profesoram, ja ṇem vērā laikmetu. P. Stradiṇu acīmredzot vēl aizvien pasargāja viṇa augstā autoritāte mediḳu un pārējā sabiedrībā, taču no pastāvīgas uzraudzības vinam vairs nebija lemts izvairīties. Visnepatîkamākais ir tas, ka jautājums tika risināts profesoram aizmuguriskā veidā, bet tādas jau bija kompartijas darbības metodes un būtỉba.

Šĩs lietas sakarā abu rosinātāju biogrāfiskie dati, kas gan ir diezgan nepilnīgi, jo dzi|ākas pēdas Latvijas medicīnas vēsturē viṇas nav atstājušas.

G. N̦ikitina-Stepanova dzimusi 1915. gadā, 1939. gadā beidza 3. L̦eningradas Medicīnas institūtu, kara dalībniece, P. Stradiṇa klīnikā strādāja no 1947. gada. Vinai nācās pārdzīvot lielas nepatikšanas, jo otrais vīrs, armijas politdarbinieks, tika arestēts par pretpadomju darbību, par ko 1949. gada 6. septembrī G. Nikitinai-Stepanovai tika izteikts partijas rājiens [6], bet 1950. g. 5. septembrī par sociālās izcelsmes slēpšanu (tēvs bijis nevis trūcīgs, bet gan pietiekami turīgs zemnieks Tatārijā) viṇa tika izslēgta no VK(b)P biedru rindām [7]. Pēc tam viṇa strādāja Tukumā un Liepājā, no 1953. līdz 1959. gadam - Rīgas Traumatologijas un ortopēdijas institūtā, izveidoja sekmīgu zinātnisko karjeru. Vēlāk G. N̦ikitina-Stepanova bija profesore Užgorodā, 1967. gadā publicēja cildinošas atmiņas par P. Stradiņu [8].

Pavisam maz zināms par A. Maslovsku: viña dzimusi 1911. gadā, 1933. gadā beidza Kazanas Medicīnas institūtu, Rīgā, tāpat kā viṇas kolēgé, ieradās kopā ar vīru virsnieku, P. Stradina klīnikā strādāja epizodiski. Aplūkoto notikumu laikā viṇa bija VK(b)P biedra kandidāte, partijā tika uzṇemta 1950. gadā tieši tās pašas sēdes laikā, kad vinas līdzdalībnieci izslēdza. 
Sekoja 1949. gada oktobra notikumi, kas jau aprakstīti, bet kurus būtu nepieciešams papildināt ar nelielu līdz šim neizzinātu deta|u. Nākamā dienā pēc Vladimira Alatirceva raksta "Par kādu kaitīgu lekciju" publicēšanas laikrakstā Sovetskaja Latvija, 15. oktobrī veselības aizsardzības ministrs Ādolfs Krauss nosūtīja vēstuli Medicīnas zinātniskās padomes priekšsēdētājam profesoram A. Šmitam ar norādījumu to apspriest, pie tam "apspriešanu nepieciešams noturēt augstā idejiski politiskā līmeñ̄”. A. Šmits savukārt padomes sekretāram docentam Aleksandram Aṇisimovam uzdeva to ieklaut padomes prezidija 17. oktobra sēdes darba kārtībā [9].

Sēdē izteicās profesori A. Šmits, Aleksandrs Liepukalns, Ernests Burtnieks, Vasilijs Kalbergs un ministra vietnieks Vladimirs Ozoliņ̌̌, bet P. Stradiņ̌̌, kas arī bija prezidija loceklis, uz sēdi nebija ieradies, tālab apspriešana tika pārcelta uz padomes prezidija un Medicīnas fakultātes kopējo sēdi 21. oktobrī [10], kuras laikā P. Stradiṇš, kā jau zināms no tagad publicētā protokola, tika iznīcinoši kritizēts.

Šeit viela pārdomām, vai P. Stradiṇa izpalikšana 17. oktobra sēdē nekluva viṇam liktenīga, jo kritika tādā gadījumā tiktu izteikta krietni šaurākā lokā un bez tik plašas rezonanses sabiedrībā. Tālab diezgan ticams liekas 1983. gadā ārzemēs publicētais Bernharda Presa apgalvojums, ka ietekmīgais pēckara laika veselības aprūpes vadītājs docents Mihails Jofe pirms liktenīgās sēdes esot P. Stradinu mierinājis, ka tas būšot tikai teātris bez nopietnām sekām [11].

Ja ar nopietnām sekām būtu domāta represēšana, tad tā patiešām izpalika, toties P.Stradiṇa pretinieki nekautrējās atgādināt šo savu uzvaru ideologiskās cīṇas frontē, turpmāk bieži un pastāvīgi noniecinot profesoru. Tā, Medicīnas fakultātes kompartijas pirmorganizācijas atskaites un pārvēlēšanu sapulcē 1949. gada 15. novembrī tās sekretārs profesors L. Golbers ziṇoja par profesora P. Stradiña pāraudzināšanas rezultātiem, bet arī citi profesori pie|aujot k|ūdas, piemēram, profesors Jānis Bune esot centies P. Stradinu attaisnot, jo viṇš lasot zinātniskas lekcijas, kas neesot saistītas ar politiku [12]. Drīz pēc tam L. Go|beram nācās izteikt izbrīnu, kā gan tā paša gada 12. decembrī Medicīnas fakultātes zinātniskās padomes sēdē, apspriežot $\mathrm{P}$. Stradiña vadītās katedras darbu, neesot tikusi skarta ne P. Stradiña nolasīto lekciju kvalitāte, ne arī viṇa katedrā veiktais idejiski politiskās audzināšanas darbs [13]. Tātad kritiķiem tomēr nācās rẹkināties ar klusu atbalstu, kas P. Stradiṇam pastāvēja fakultātē.

Netika taupīti arī profesora tuvākie līdzstrādnieki. Piemēram, prof. A. Liepukalns fakultātes kompartijas pirmorganizācijas sapulcē 1950. gada 31. martā par steidzami likvidējamu apkaunojumu uzskatīja to, ka P. Stradiṇa un J. Bunes asistenti nezinot tēvzemes (proti, Krievijas, PSRS) kirurgus [14]. Asistente Vera Kuroša norādīja, ka P. Stradiṇa asistenti Êvalds Ezerietis un Veronika Rozenbaha "saindē müsu studentu apziṇu" [15]. V. Rozenbahai vēl tika pãrmests, ka viņa sabotējot agitatora pienākums [16], Veltai Brambergai - ka viṇa esot politiski neuzticama [17]. 
P. Stradinamam adresēta kritika nerimās arī pēc Rīgas Medicīnas institūta izveidošanas. Asistents Sergejs Borovkovs 1951. gada 18. decembrī žēlojās kompartijas pirmorganizācijai par P. Stradiña vadīto katedru un klīniku, kur studenti esot apolitiski un nelasot avīzes, māsas atsakoties runāt krieviski, pats P. Stradiṇ̌s neņemot vērā komunistu aizrādījumus, P. Stradiṇš un Ē. Ezerietis "tur monopolu" un nejaujot operēt jaunajiem [18].

Pēc S. Borovkova atkārtotas sūdzības, ka katedrā viṇu uzskatot par "svešǩermeni", 1952. gada 2. februārī tika ierosināts izveidot jaunu kārtējo komisiju P. Stradiña klīnikas darbības pārbaudei [19].

Profesora Paula Stradiṇa vajāšanas hronikā pēckara gados ir palikušas neizzinātas arī vairākas citas lapas, ne velti dažas svarīgas dokumentu mapes (piemēram, Veselības aizsardzības ministrijas nomenklatūras darbinieka lieta) arhīvā nav saglabātas, varbūt pat ir iznīcinātas. Taču pētnieciskā darba iespējas arī vēl ne tuvu nav izsmeltas, jāmeklē pamatīgāk.

\section{Vēres}

1. Stradinšs J., Arons K. E., Vīksna A. Tāds bija mūsu laiks... - R., 1996. - 163. 245. Ipp.

2. LVA PA, 788. f., 2. apr., 1. 1., 5. Ip.

3. LVA, 1022. f., 14. apr., 3. 1., 5., 18. lp.

4. LVA PA, 101. f., 9. apr., 45. 1., 204. Ip.

5. Turpat, 788. f., 2. apr., 1. 1., 30. Ip.

6. Turpat, 1. apr., 8. 1., 31. 1p.

7. Turpat, 10. 1., 7. Ip.

8. Никитина-Степанова Г. Г. Руководитель и воспитатель // Павел Иванович Страдынь - врач, ученый, человек. - Р., 1967. - С. 239-243.

9. LVA, 1022. f., 6. apr., 27. 1., 219. Ip.

10. Turpat, 222., 229. Ip.

11. Press B. Errungenschaften der sowjetischen Medizin in Lettland. - Berlin, 1983. S.87-88.

12. LVA PA, 788. f., 1. apr., 8. 1., 119. Ip.

13. LVA, 1340, f., 10. apr., 16. 1., 9. Ip.

14. LVA PA, 7222. f., 1. apr., 1. 1., 38. Ip.

15. Turpat, 2.1., 29. Ip.

16. Turpat, 1.1., 132. lp.

17. Turpat, 2. 1., 18. Ip.

18. Turpat, 161. lp.

19. Turpat, 3. 1., 13. Ip. 


\section{Latvijas Valsts universitātes partijas birtoja sēdes 17. protokols}

\section{9. gada 21. jūnijā}

Piedalās Pugo, Jurgens, Miške, Sergejeva, Tabaks, Meščaṇinovs, Ginters, $\bar{A}$ boliņš, no K(b)P Kirova rajona komitejas b. Nikolajevs, veselības aizsardzỉbas ministra vietn. b. Grigorašs un uzaicinātie biedri.

\section{Dienas kārtība:}

1. Komunistu bb. N̦ikitinas un Maslovskas iesniegums par neciešamiem darba apstāk|iem Fakultātes ḳirurgijas katedrā.

$[\ldots]$

Klausījās:

Brigādes apsekošanas akts par bb. N̦ikitinas un Maslovskas iesniegumu (ziṇo b. Daṇilovs ${ }^{1}$ ).

Uzstājas:

b. Maslovska. Savā iesniegumā mēs norādījām neprecīzi, jo katedrā nemīl ne jau krievu, bet gan padomju ${ }^{2}$ ārstus. Valsts klīniskā slimnīca ir mūsu universitātes bāze. Klīnikas kolektīvs sastāv no cilvēkiem, kas strādājuši Ulmaṇa laikā. Pietiekami pateikt to, ka tad, kad es atnācu darbā uz klīniku, profesors Stradiṇ̌̌ mani uzreiz apstulbināja, sakot, - mēs jūs pieņemam darbā tikai uz desmit mēnešiem. Darba atmosfēra neapšaubāmi ir smaga, kolektīvs jāpārveido. Visiem ir pazīstama anarhija profesora Stradiṇa dabā, ik dienas viṇ̌s runā vienu un to pašu, - ka krievu asistenti viṇam nav vajadzigi, jo latviešu pietiekot. Mums jāpasaka, ka b. Burtnieks ${ }^{3}$ nereagēe uz visiem signāliem. Mēs esam parādījuši pietiekamu aktivitāti katedrā. Fakultātes vadībai un partijas organizācijai ir jāveic klīnikas kadru pārkārtošana.

b. N̦ikitina. Katedrā es strādāju no 1947. gada maija. Lĩdzstrādnieks, kura vietā mani pieṇēma, jau laikus mani sagatavoja tai uzṇemšanai, kuru man nāksies sagaidīt no klīnikas aparāta puses. Autoritāti nācās iekarot ar neatlaidīgu darbu un uzstājību. Atrodoties klīnikā, man nācies operēt tikai divu slimību gadījumos. Kad es griezos pie profesora Stradiṇa, kāpēc man maz dod operēt, viņš paziņoja, - es jums neuzticos.

1 Nikolajs Danilovs (1900-1991), fiziologs, profesors, LVU un RMI katedras vadītājs (1949-58), vēlāk strādāja Rostovā pie Donas.

2 Tolaik par padomju ārstiem dēvēja kolēg̀us, kas darbā Latvijā bija ieradušies no vecākām PSRS republikām. Vietējie ârsti acīmredzot par padomju ārstiem vēl uzskatīti netika.

3 Ernests Burtnieks (1898-1958), terapeits ftiziatrs, profesors, LVU un RMI katedras vadītājs (1947-58), LVU Medicīnas fakultātes dekāns (1949-50), Republikas klīniskās slimnīcas galvenais ârsts (1947-51), vēlāk - RMI direktors. 
b. Golbers ${ }^{4}$. Mēs uzklausījām brigādes locek|a b. Daṇilova zinojojumu, kurā viss precīzi pateikts. Būdama fakultātes partijas biroja locekle un sekretāra vietniece, b. N̦ikitina nezin kāpēc divu gadu laikā nav izvirzījusi šo jautājumu apspriešanai, lai likvidētu trūkumus. Minēto jautājumu viņas izvirzīja tikai tāpēc, ka tas skar viṇu pašu. Profesors Stradiņš ir loti neorganizēts cilvēks, viṇš daudz par ko cīnās, - tāda ir viṇa rakstura iezīme. Bet, ka viņ̌̌ it kā nostātos pret padomju cilvēkiem, - tas ir nepareizi. Profesora Stradiṇa trūkums ir tāds, ka četru gadu laikā viṇš nav spējis sagatavot kvalificētus ārstus ḳirurgus. Klīnikā b. Maslovska atnāca ar desmit gadu stāžu. Mēs b. Maslovskai paziṇojām, ka komunistus atstāsim katedrā. Pašlaik katedrā ir tāds stāvoklis, ka jāatstāj viens krievvalodīgs asistents. Bija laiks, kad profesors Stradiṇš kūdīja vienu pret otru, lai katedrā atstātu vienu asistentu. Mums fakultātē ir 30 komunistu starp pasniedzējiem, ir daudz asistentu partijas biedru un Tēvijas kara dalībnieku. Nevarētu teikt, ka visi cilvēki ir tīri, un mums ar viņiem būs vēl daudz jāstrādā. Uzskatu, ka šo jautājumu nedrīkst aplūkot tīri tendenciozi. Jāsakārto klīnikas darbs.

b. Kuroša ${ }^{5}$. Es loti vēlējos atklāt ienaidniekus, bet tos pamanīt mums bija loti grūti. Patiesi fakti par ienaidnieku izlēcieniem netika norādīti. Es uzskatu, ka mums ir jānoskaidro, kas ir šie ienaidnieki - profesori, docenti, šveicari u.tml., lai ar viṇiem cīnītos. Es nepie|auju tādu faktu, ka sanitārs izrauj şłirci no ârsta rokām, kā to stāstīja b. N̦ikitina, lai pēc tam šo jautājumu atstātu bez reakcijas. Mūsu padomju ārsti autoritāti neiekaroja uzreiz, lūk, tāpēc katedrā izveidojās šāds stāvoklis. Es nekad nepie|autu padomju ārsta aizskaršanu. Kādus es varu izdarīt secinājumus?

Faktu par klīnikas darbinieku pretpadomju attieksmi mums nav. Vajag ārstus komunistus, kas beiguši padomju skolu, izvirzīt vadošã darbā par noda|u vadītājiem. Studentu audzināšana jāveic uzmanīgi, atstājot darbam katedrā ārstus komunistus.

b. Silecka ${ }^{6}$. Darbā ar profesoru Stradiṇu viṇa attieksme pret mani sākumā bija nelabvēlīga, bet pēc tam noregulējās. Man liekas, ka divas komunistes, strādājot katedrā, ir nepietiekami parādījušas savu organizētỉbu. No komunistu puses pārrunu ar katedras vadību nav bijis. Šīsdienas partijas biroja sēde norādīs komunistēm N̦ikitinai un Maslovskai, kā pārkārtoties darbā.

4 Leonīds Golbers (dz. 1909), patofiziologs, profesors, LVU un RMI katedras vadītājs (1947-58), LVU Medicīnas fakultātes kompartijas pirmorganizācijas sekretārs (1947-50), vēlāk strādāja Maskavā.

5 Vera Kuroša (1909-1994), ginekologe, LVU un RMI docētāja (1948-68).

6 Margarita Sijecka (dz. 1908), anatome, LVU un RMI docētāja (1947-76). 
b. Grigorašs ${ }^{7}$, veselības aizsardzības ministra vietnieks. Un tomēr katedra un klīnika nav sasniegusi mūsu kopīgo mērki. Ārstu kadri četru gadu laikā nav sagatavoti. Šīs lietas defekts ir darba plāna trūkums. Mums nepieciešams, lai katram ārstam būtu operāciju diena. Šis defekts ir neapšaubāmi acīmredzams. Mūsu uzdevums ir pāraudzināt darbiniekus. Ja ārsts ir zinošs, vinšs bauda autoritāti. Mēs, komunisti, neatrodamies priekšgalā. Nacionālo kadru jautājums ir liels jautājums. Jums kā ārstiem komunistiem jāaug intensīvāk.

b. Jurgens ${ }^{8}$. Partijas birojam jāpajautā biedriem, ja jau viṇi strādā aptuveni divus gadus, tad tikai kāpēc tagad paziṇo, ka viṇus apspiež. Es domāju, ka tad, kad biedrenes N̦ikitina un Maslovska gāja strādāt, situācija bija nelaipna. Bet komunistus sūta, lai sakārtotu darbu. Kad mēs bijām Augstākās izglītības ministrijā un ziṇojām par pretpadomju cilvēkiem, kas strādā pie mums, universitātē, mums pateica, lai nenodarbojamies ar tenkām, bet minam faktus. Autoritāti iekaro ar darbu, bet divu gadu laikā komunistes N̦ikitina un Maslovska nekādus pārkārtojumus katedrā nav veikušas. Es domāju, ka komunistiem, kas strādā jebkurā iecirknī, ir jābūt kaujinieciskākiem, aktīvākiem. Atklāt faktus, kas gan tur notiek. Man liekas, ka skaidrojums jāmeklē tur, ka viṇas nestrādā ar sevi, neapgūst marksismu-leninismu.

b. Meščaṇinovs ${ }^{9}$. No tādas faktu bagātïbas tomēr izteikti redzams, ka klīnikā pastāv noteikta darbinieku kadru atlase. Šis fakts izraisa bažas, - kāpēc šĩ cilvēku grupa ir tik vienota. Šādā lielā kolektīvā, kas veic jauno padomju ārstu audzināšanu, ir cilvēki ar pretpadomju noskaņojumu. Mums jāpieṇem vienprātīgs lēmums - izkliedēt šo atmosfēru.

b. Āboliṇs $\check{r}^{10}$. Bb. N̦ikitinas un Maslovskas iesniegumā ir dala patiesības. Šai kolektīvā ir daudz mums svešu nacionālistisku uzskatu. Klīnikas atmosfẽra ir neveselīga, šos cilvēkus ir jāpāraudzina un jāpārgrupē. Profesoru Stradiṇu mēs cienām kā labu profesoru. Sodien mēs izvirzām jautājumu par viṇa apolitiskumu. Bet vienu lietu gan vajadzētu vērīgi uzraudzìt, - kā viṇš audzina ārstus. Padomju ārsts komunists vienmēr atradīs darbu. Es domāju, ka bb. N̦ikitina un Maslovska no sirds pārdzīvo arī par kolektīvu. Viṇām ir taisnība, ka vērīgi jāseko profesoram Stradinam.

b. Nikolajevs, LK(b)P Kirova rajona komiteja. Es vēlētos, lai partijas birojs nodarbotos ar šo jautājumu, jo klīnika slikti veic zinātnisko darbu, un

7 Fjodors Grigorašs (1906-1984), LPSR veselības aizsardzỉbas ministra vietnieks (1947-50), vēlāk - RMI katedras vadītājs un profesors.

8 Jānis Jurgens (1900-1983), ekonomists, profesors, LVU prorektors (1949), rektors (1949-62).

9 Jefims Meščaninovs (1900-1983), kara ārsts, LVU un RMI docētājs (1947-55), vêlāk - RMI zinātniskais sekretārs.

10 Jānis Āboliṇš (1893-1958), LVU kompartijas biroja sekretârs (1945-47, 1952-54). 
tajā ir cilvēki, kas neizraisa uzticību. Acīmredzot nāksies veikt kadru pārgrupēŠanu. Sāpīgākais ir tas, ka bb. N̦ikitina un Maslovska ir iedomājušās vērsties partijas birojā tikai pēc diviem gadiem. Domājams, ka biedrenes ir jutušãs kā bārenītes" ${ }^{11}$ Jūs neatradāties komunistam pietiekami augstā līmenī. Vajadzēja tūlīt iet uz partijas biroju un ierosināt jautājumu. Es vēlos, lai šodien, partijas biroja sēdē, jūs saprastu, ko no jums vēlas partijas birojs. Un lai visi komunisti, kas nosūtīti darbā, veicinātu partijas un valdības politiku.

b. Plaude ${ }^{12}$. Pašlaik Medicīnas fakultātē ir slikti ar kvalifikācijas celšanu. Fakultāte slikti sagatavojās, un sistēma kvalifikācijas celšanā nepastāv. Nepieciešams tūlīt un loti nopietni sagatavot zinātniskās kvalifikācijas celšanas plānu. Šis jautājums jāatspoguḷo lēmumā.

b. Pugo ${ }^{13}$. Domāju, ka pareizi ir tas, ka bb. Nikitina un Maslovska to rūgtumu, kas vin̄ām bija radies, nodeva partijas birojam, kaut ar lielu aizkavēšanos. Šie fakti pelnī loti lielu ievērību, un ar to jānodarbojas fakultātes partijas organizācijai. Man liekas, ka ierosinot šos jautājumus, N̦ikitina un Maslovska ir rīkojušās neprecīzi ${ }^{14}$. Savā iesniegumā viṇas norāda, ka krievu ārstus Šeit nemīl. Kapēc gan tāds neveselīgs jautājums netika uzdots partijas organizācijai? Vai mēs varam teikt, ka mums nav buržuāzisko nacionālistu, - viṇi ir, un mūsu uzdevums ir vinuus atmaskot. Atbrīvoties no komunistiem katedrā mēs nedomājam. Augstākās izglītỉbas ministrijā mēs izvirzijāām uzdevumu par mūsu universitātes nostiprināŠanu ar speciālistiem komunistiem. Jums vairāk vajadzēja parādīt faktus par attieksmi pret krievu speciālistiem. Ar šo jautājumu jānodarbojas fakultātes partijas organizācijai un jāizdara atbilstoši secinājumi arī par citām katedrām.

\section{Lēmums}

Uzklausījis bb. Nikitinas un Maslovskas iesnieguma izskatīšanas brigādes veiktās pārbaudes rezultātus, iesniedzēju mutiskos ziṇojumus, kā arī LVU partijas komitejas biroja locek|u, brigādes locek|u, veselības aizsardzības ministra vietnieka b. Grigoraša un Kirova rajona partijas komitejas pārstāvja b. Nikolajeva viedoklus, LVU partijas birojs atzīmē nenormālos darba apstāklus profesora P. Stradina klīnikā, kas izpaudušies tādējādi, ka klīnikā trūkst ikdienas kontroles par zinātniskā darba plāna izpildi, kā rezultātā četru gadu laikā nav pabeigtas klīnikā sāktās disertācijas. Klīnikā vāji tiek veikts tās darbinieku ideologiskās pãraudzināšanas darbs. Ārsti komunisti nav ieñēmuši avangarda lomu šajā vissvarīgākajā darba iecirknī. Balstoties uzklausītos materiālos un viedokłos,

11 “чувствовали себя казанскими сиротами".

12 Kârlis Plaude (1897-1975), siltumenergētikis, LVU prorektors (1947-50), vềāk profesors, LPSR ZA akadēmiḳis un prezidents.

13 Kārlis Pugo (1896-1955), LVU kompartijas biroja sekretārs (1948 49), prorektors (1949-52), LK(b)P CK loceklis. 
LVU partijas birojs nolemj:

1. Asistentu Maslovskas un N̦ikitinas iesniegumā minētie trūkumi profesora Stradina katedras darbā nevar tikt novērtēti kā rezultāts tam, ka profesors Stradiṇš kategoriski nevēlas palīdzēt, apmācīt un sekmēt padomju ārstu tālāku virzību, kā tas norādīts iesniegumā.

2. Pievērst Valsts klīniskās slimnīcas partijas un sabiedrisko organizāciju un katedru vadītāju uzmanību nepieciešamībai pastiprināt kā organizatorisko, tā arī audzināšanas darbu klīniku darbinieku vidū, un pastiprināt kritiku un paškritiku ar nolūku izlabot k|ūuas darba procesā.

3. Ieteikt Medicīnas fakultātes partijas birojam savās sēdēs sistemātiski uzklausīt katedru vadītāju atskaites kopā ar piestiprināto partijas biedru līdzziņojumiem.

4. Pievērst Valsts klīniskās slimnīcas galvenā ārsta prof. Burtnieka uzmanību nepieciešamībai pārskatīt nodalu vadītājus ar nolūku saglabāt vadošos amatos padomju veselības aizsardzībai vērtīgākos darbiniekus.

5. leteikt Medicīnas fakultātes dekānam novērst brigādes konstatētos trūkumus organizatoriskā darbā un pastiprināt sistemātisku kontroli pār zinātnisko kadru izaugsmi.

6. Nemot vērā nevienmērīgo VK(b)P biedru sadalījumu LVU Medicīnas fakultātes ḳirurgíisko klīniku asistentu sastāvā, uzskatît par lietderīgu saglabāt štatā visus asistentus ķirurgus partijas biedrus, sadalot tos vienmērīgi starp visām Cetrām ḳirurǵijas katedrām.

LVU partijas biroja sekretārs (K. Pugo)

LVA PA, 788. f., 1. apr., 7. 1., 182.-187. Ip. Tulkojums no krievu valodas.

\section{One More Page from the Persecution Chronicle of Paul Stradiņš: Publication of Past Evidence (Summary)}

The minutes of the 1949 session of June, 21 of the Communist Party Bureau of Latvia's University have been published, where the complaint by Galija NikitinaStepanova and Alexandra Maslovska is discussed about the insupportable conditions of work at the Chair of Faculty Surgery headed by Prof. P. Stradiņ̃ and a resolution adopted to improve them. Introduction and comments by A. Vîksna.

Arnis Vīksna, Dr. med. h.c., profesors

LU Medicīnas fakultāte

Raiña bulv. 19, Rīga, LV 1586 Latvija 